\title{
市民参加型ヒートアイランド調 CITIZEN PARTICIPATIVE RESEARCH 査手法の開発 METHOD ON URBAN HEAT ISLAND
}

\section{饗庭 伸 一 $*$ - 1 \\ 中山哲士 — $* 3$ \\ キーワード : \\ まちづくり，ヒートアイランド，市民参加}

住田旭宏 — - *2

諸岡俊祐 — $* 4$

Keywords:

Community based planning, Urban heat island, Citizen participation

\section{Shin AIBA \\ Akihiro SUMITA - $* 2$ \\ Satoshi NAKAYAMA - $* 3$ \\ Shunsuke MOROOKA $-* 4$}

It is necessary to make a plan that reduce the heat island effect in the medium- and long-terms. And the plan is realized by local citizen who has deeper appreciation of urban thermal environment. In this research we developed method for citizens' participation about urban thermal environment. One is survey of the urban thermal environment with citizen named "Walking survey" and "Cool spot survey" in Kawasakishi Takatsu-ku. The other is WEB system which share outcomes of the survey. Additionally, we got evaluation of participants with hearing investigation.

\section{1. 背景と目的}

ヒートアイランド現象について様々な対策が講じられている。行政 や民間企業による対策だけではなく、一般市民の意識を変え、具体 的な対策行動を促進することが不可欠である事は言うまでもない。 これまで市民を対象にした取り組みとして、打ち水をイベント的に 行う、グリーンカーテンを促進するなど、個別的かつ短期的な対策 は多く取り組まれてきた。これらは一定の成果を挙げているものの、 個別的であるが故に地域での取り組みには広がりにくく、例えば「風 の道」を形成するなどの中長期的な対策にも繋がりにくい。面的な 地域を対象にして、地域社会を巻き込んで持続的に市民の意識を形 成し、そこから中長期的な様々な対策行動につなげていく取り組み が必要である。

そこで本研究では、特定の地域を対象として、市民が参加してヒー トアイランド現象を調査し、その結果を地域で共有する市民参加技 術の開発を行った。調査を市民が協力して行うことが意識の形成に つながり、その結果は中長期的な対策の基礎デー夕となる。

具体的には、2 年間にわたって連続した調査やワークショップ等を 開催し、その結果を共有した。そしてこれらに対して、どういった 市民が参加し、調査結果がどう理解され、終了後に意識がどう形成 され、具体的な対策行動につながるかどうかについて、市民の評価 を調査した。本報告の前半では開発した市民参加技術を報告し、後 半では参加者 5 名へのインタビュー調査からその評価を報告する。

既往研究には、「都市環境気候図」を市民参加のもとで作成し、こ れを利用したワークショップを行う取り組む田中ら ${ }^{1)}$ 日本建築学会 2)334)5) の研究、参加者が屋外を徒歩で移動して実測し体感を評価す
る増田ら ${ }^{6)}$ の研究がある。市民参加型で調査を行うという点では共 通しているが、筆者らの技術は、詳細な気温把握をするという調査 手法に特徴があること、デー夕の共有手法までを開発したこと、継 続的な参加者を得て 2 年間にわたって取り組んだ事に新規性がある。

\section{2. 研究対象区域と期間}

神奈川県川崎市高津区における約 $3.5 \mathrm{~km}$ 四方の範囲を対象として、 2009 年から 2010 年にかけて取り組みを行った（図 1)。二つの鉄 道が交差する地域であり、中心的な鉄道駅を含む 5 駅が含まれ、東 西南北に幹線道路や高速道路が地区を貫いている。自然的地理とし ては、多摩丘陵の東端部である南西部の丘陵地帯と多摩川が形成し た平坦な土地に分かれ、多摩川、多摩川の支流である平瀬川、農業 用水である二ケ領用水を有す。江戸時代以前から続く歴史を持つ一 方で、戦後に東京のベッドタウンとして発達したエリアでもある。 高津区役所では 2008 年度より「エコシティたかつ」というマス夕 ープランを策定し、市民が参加する委員会を設置して、区の施策の 様々な分野において、公民協働型で地球環境問題への対策を推進し ている㗟1)。本研究は研究者のサイドから発意されたものであるが、 同マスタープランの施策の一部として正式に位置づけられ、区役所 および区民の協力を得た。

このように、都心的な空間と自然的な空間が存在し、地形も変化 に富むなど、ヒートアイランド現象に影響を与える多様な要素が存 在している。環境問題に対する市民参加の取り組みの蓄積もあり、 ある程度の経験を持つ市民の参加も見込まれたため、調查対象区域 として選定した。

\footnotetext{
‘1首都大学東京都市環境学部建築都市コース 准教授・博士 (工学)

(三 192-0397 八王子市南大沢 1-1)

清水建設侏国際支店シンガポール営業所

岡山理科大学工学部建築学科 准教授・博士 (工学)

首都大学東京都市環境科学研究科建築学域博士前期課程

'1 Assoc. Prof., Division of Architecture and Urban Studies, Tokyo Metropolitan Univ., Dr. Eng.

International Division, Shimizu Corporation

*3 Assoc. Prof., Dept. of Architecture, Faculty of Engineering, Okayama Univ. of Science, Dr. Eng.

*4 Master Course, Dept. of Architecture and Building Engineering, Tokyo Metropolitan Univ.
} 


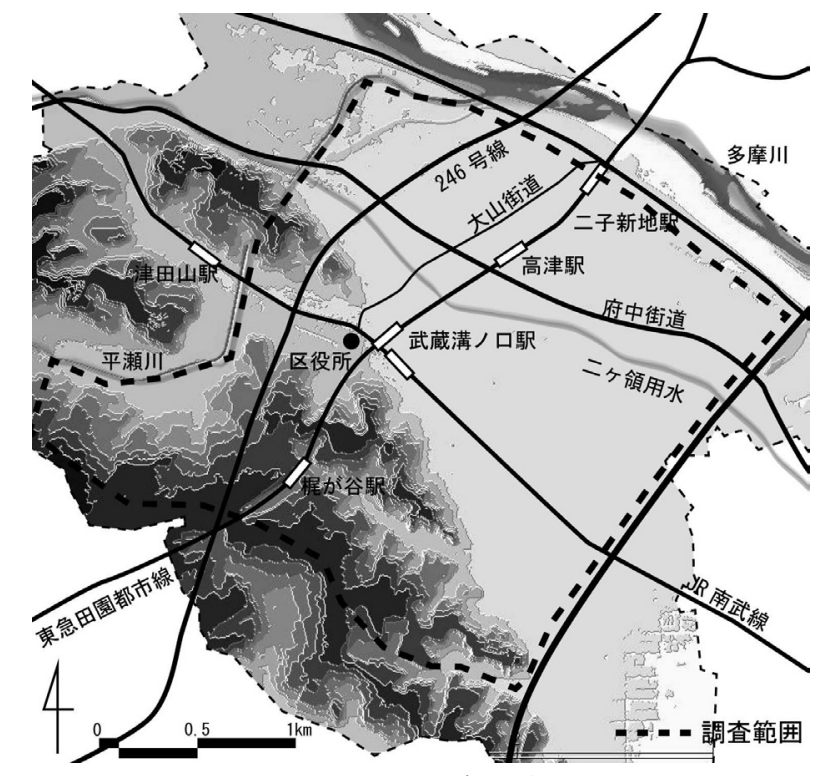

図 1 研究対象区域

3. 全体プログラム

本報告の前半部では開発した市民参加技術を報告する。市民参加技 術は、(1)市民参加型の調査と(2)その結果を地域で共有する手法で構 成される。調査については、街を歩いて対象地区全体の気温分布を 計測する「街歩きによる気温実測調査」と、その結果から明らかに なった気温が低い場所＝クールスポットを対象に、気温や周辺環境 の変化を継続的に計測・調査する「クールスポット調査」の 2 種の 調査を行い、それぞれの結果の共有手法を開発した。

2 年間の全体プログラムを示す（図 2 )。「街歩きによる気温実測 調査」は 8 回の調查を行った。夏期と冬期のそれぞれ早朝と日中に 気温の調査を行い、2009 年度は調査対象エリアの全体を対象にした 調査を、2010 年度はエリアの中の 2 地区を選定し、エリアを絞った 詳細な調査を行った。「クールスポット調査」は2010 年の夏期に約 2 ケ月にわたって 40 カ所の実測調査を行い、 11 月から 1 月にかけてそのうち 22 力所の現 地調査を行った。それぞれの調査結果を共有 するウェブサイトを開発し、「街歩きによる 気温実測調査」の結果については 2009 年 8 月からの運用を、「クールスポット調査」の 結果については 2010 年 8 月からの運用を行 つている。これらに加えて、調査の目的や結 果等を共有する 5 回の「ワークショップ」を 開催した。

参加者への呼びかけは 2009 年 7 月の川崎 市の広報で呼びかけられたほか、「エコシテ イたかつ」に関係した区民への直接的な呼び かけを行い、各回で $3 \sim 7$ 名の参加を得た。 また、「クールスポット調査」の 40 力所の実 測調査については、対象地域の町内会・自治 会を通じて声がけが行われ、20名の参加を 得た。全体を通じて一度でも参加をした区民

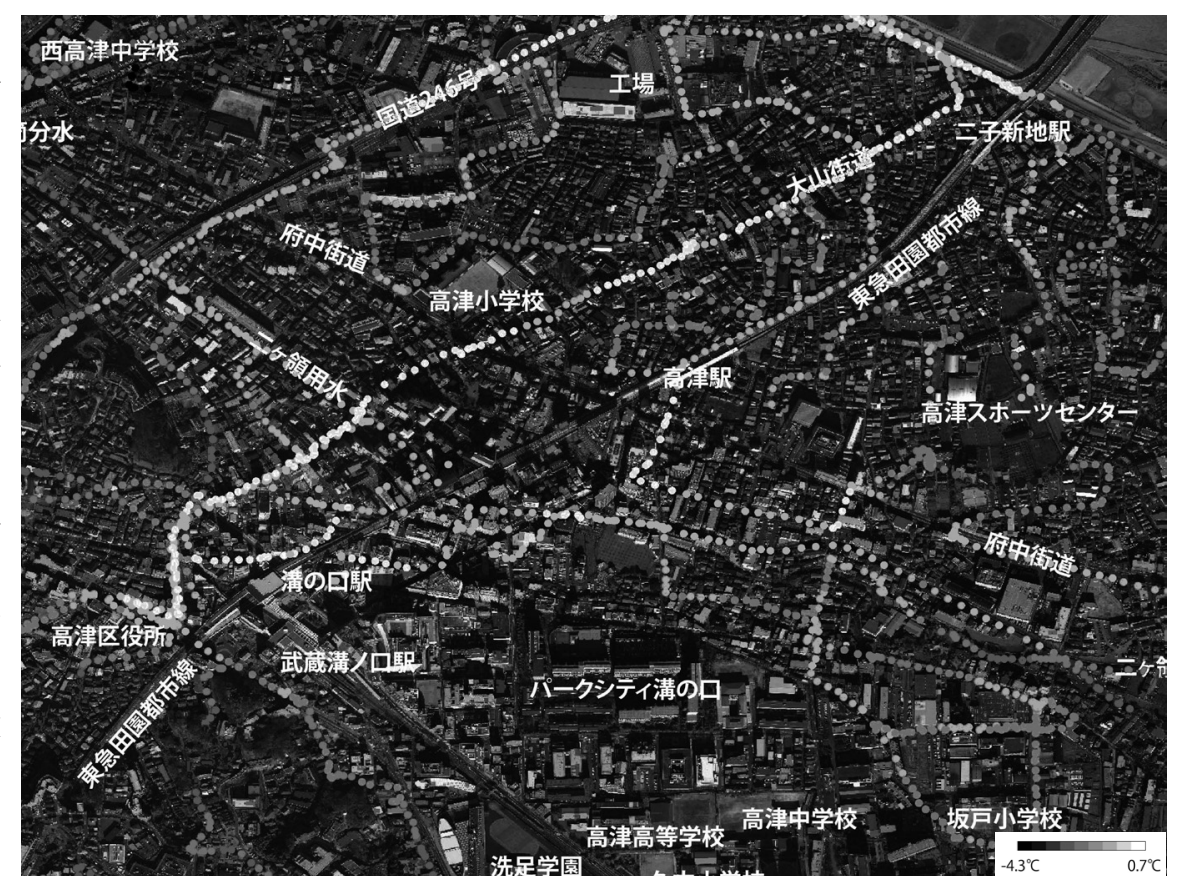

図 3 街歩きによる気温実測調査の結果の例（2010 年1月15 日早朝の調査結果/部分/カラー図を白黒化）
は 20 名であり、その中で継続的に参加したコアとなる参加者は 6 名 であった。個別プログラムは各回の完結性が高く、単発的な参加が 可能な形式をとった。運営側は大学スタッフが 4 名、区職員が 1 名 であり、加えて調査の人手が必要な場合には学生スタッフや区の職 員が集められた。

それぞれの調査手法と共有手法およびワークショップについて、 次章で詳細に報告する。

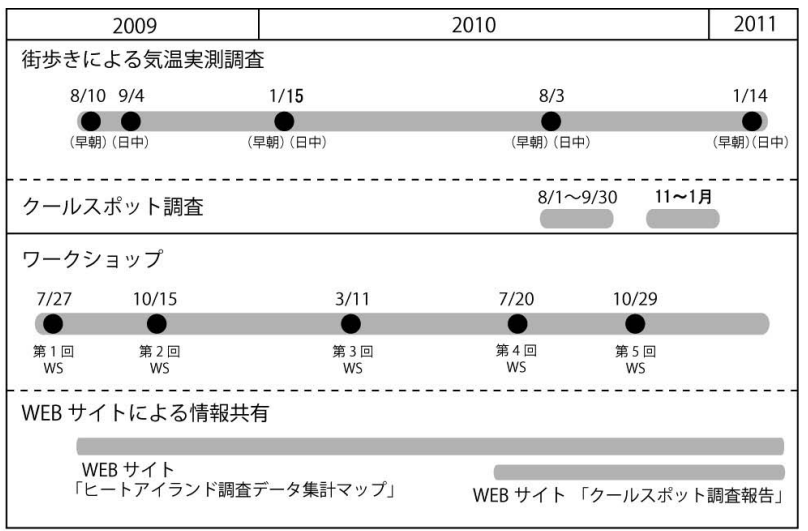

図2 全体プログラム

4. 個別の手法

4.1 街歩きによる気温実測調査

1) 概要

同時点での都市の気温を、歩行調査によって実測し、詳細なスケー ルで都市の温熱環境を明らかにする調査である。調査の結果として、 図 3 のような情報を得る事が出来る。参加者にとつて、自らが歩き ながら気温の測定をすることによって、実際に生活する際に歩く道 路空間の気温を詳細に知る事が出来る。

\section{2) 調査手法}

調査対象区域を $2 \sim 3$ 時間で歩行出来る区域にわけ、区域内を網羅 する調査ルートを設定し、調査担当者が、GPS ロガーと電子温度計 


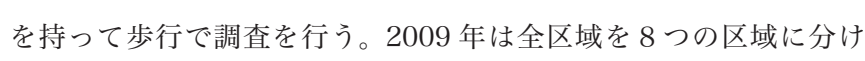
て実施し、2010 年はそのうち2つの区域を選定して調査を行った。 2010 年の区域は多摩川沿いのやや密集した市街地と、丘陵地で複雑 な地形を持つ市街地という特徵的な区域を対象とし、ほぼ全ての街 路を対象に調査を行った。

GPS ロガーで一定の時間毎に位置情報を記録し、電子温度計によ り気温を記録した。計測後に時刻データを用いて位置情報と気温の デー夕を照合し、位置情報を持った気温の情報を得る。正確な計測 の為、機材は画板に貼りつけ体から一定距離離して計測した (図 4 )。 デー夕は 5 秒每に測定し、成人の標準的な歩行速度 (時速 $4 \mathrm{~km}$ ) を勘 案すると、おおよそ $5.5 \mathrm{~m}$ 毎の気温デー夕が測定されたことになる。

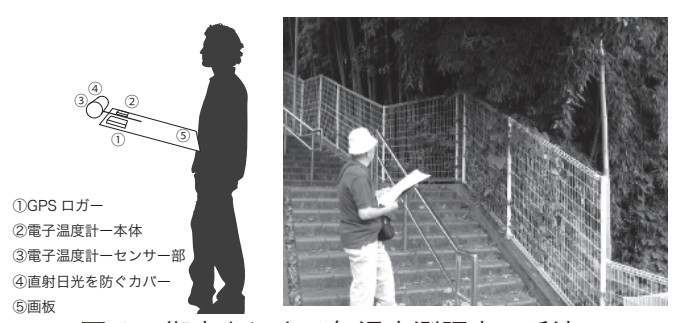

図4 街歩きによる気温実測調査の手法

調査は、夏季と冬季それぞれの早朝 (2 時〜日の出) と日中 ( 正午 〜 3 時) に行った (表 1 )。ヒートアイランド現象は日射の影響を受 けない冬期の早朝に最も顕著に現れるため、冬期早朝の気温を計測 を基本にしつつ、市民の体感として最も暑い夏期の日中の計測も行 い、比較をするために、それぞれの日中と早朝の計測を行った。

なお、各測点に計測時刻の差が生じるため、気温デー夕の時刻補正 を行った。調査時に高津区役所敷地を基準地点として定点の気温を 測定し、基準となる時刻からの時間変化分だけを補正量として取り 除くことによって最終のデー夕を補正した。

表 1 調査の日時と参加人数

\begin{tabular}{|c|c|c|c|c|c|c|c|c|c|}
\hline \multirow{2}{*}{\multicolumn{2}{|c|}{$\frac{\text { 季節 }}{\text { 測定日 }}$}} & \multicolumn{2}{|c|}{ 夏 } & \multicolumn{2}{|c|}{ 冬 } & \multicolumn{2}{|c|}{ 夏 } & \multicolumn{2}{|c|}{ 冬 } \\
\hline & & 09年8月10日 & 09年9月4日 & \multicolumn{2}{|c|}{ 10年1月15日 } & \multicolumn{2}{|c|}{10 年 8 月 3 日 } & \multicolumn{2}{|c|}{ 11年1月14日 } \\
\hline \multicolumn{2}{|c|}{ 時間带 } & 早朝 & 日中 & 早朝 & 日中 & 早朝 & 日中 & 早朝 & 日中 \\
\hline \multicolumn{2}{|c|}{ 測定時間 } & $\begin{array}{c}2: 00 \sim \\
4: 00\end{array}$ & $\begin{array}{c}13: 00 \sim \\
15: 00\end{array}$ & $\begin{array}{c}2: 00 \sim \\
5: 00\end{array}$ & $\begin{array}{rl}13: 0 & 0 \\
15: 0 & 0\end{array}$ & $\begin{array}{c}2: 00 \sim \\
5: 00\end{array}$ & $\begin{array}{c}13: 000 \\
15: 00\end{array}$ & $\begin{array}{c}2: 00 \sim \\
5: 00\end{array}$ & $\begin{array}{r}13: 000 \\
15: 00\end{array}$ \\
\hline \multicolumn{2}{|c|}{ 天候 } & $\begin{array}{l}\text { 曇り後雨 } \\
\text { (4时で中止) }\end{array}$ & 晴れ & 晴れ & 晴れ & 晴れ & 晴执 & 晴れ & 晴れ \\
\hline \multirow{5}{*}{ 人数 } & 住民 & 3 & 5 & 3 & 5 & 2 & 3 & 2 & 3 \\
\hline & 学生 & 10 & 4 & 8 & 7 & 13 & 9 & 13 & 9 \\
\hline & \begin{tabular}{|l|} 
区職員 \\
\end{tabular} & 3 & 4 & 3 & 1 & 4 & 4 & 4 & 4 \\
\hline & \begin{tabular}{|l|} 
研究者 \\
\end{tabular} & 3 & 5 & 2 & 4 & 3 & 3 & 3 & 3 \\
\hline & 合計 & 19 & 18 & 16 & 17 & 22 & 19 & 22 & 19 \\
\hline \multicolumn{2}{|c|}{ ルート数 } & 8 & 8 & 8 & 8 & 8 & 8 & 8 & 8 \\
\hline
\end{tabular}

\section{3) 調査結果の概要}

2010 年 1 月の早朝の調査結果を見ると、中心駅の周辺や幹線道路 沿いの気温が高くなっているのに対し、傾斜の多い地域や緑の多い 地域の気温が低くなっている。狭いエリアの中でも気温が 4 度ほど 異なることが明らかになった（図 3 )。参加者からは、日常的な感覚 として理解していた気温の変化が、あらためて計測データという形 で示され、再確認をすることが出来た、といった感想が聞かれた。

4) 共有手法

調査結果を共有するために「温熱環境データ集計マップ」と名付け たWEB サイトを開発した（図 5 )。サイトにログインし、調査日時、 表示させるデー夕の数、測定範囲を選択すると、地図上に調査結果
が表示される。Google Maps をベースにしているため、地図だけで なく航空写真とも重ねて見ることが可能である。インターネットを 通じてデータをサーバーにアップロードすれば、閲覧が可能になる システムである。各調査後にデータをアップロードしその場で結果 を参加者と確認したほか、全ての調査のデータをアップロードして 後日の閲覧を可能とした。

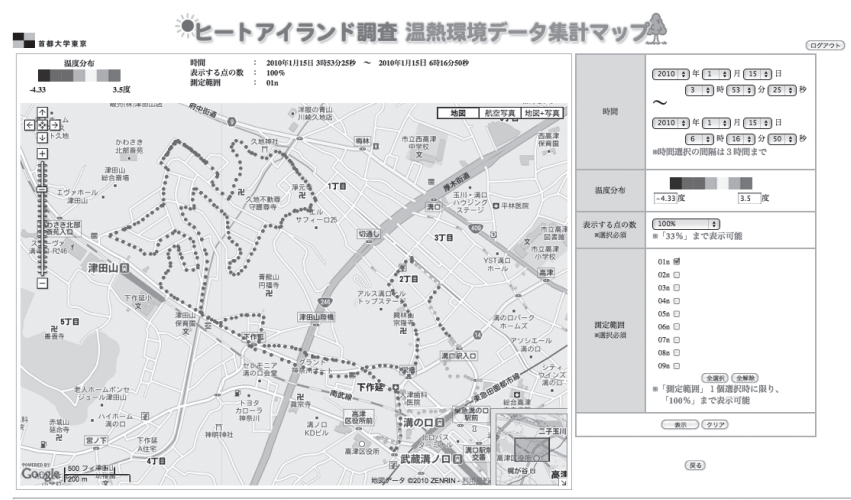

図 5 温熱環境データ集計マップ

\section{2 クールスポット調査}

\section{1) 概要}

街歩きによる気温実測調査で明らかになった結果から、市街地の中 で特に気温が低い「クールスポット」を抽出して継続的な調査を行 った。街歩きによる気温実測調査は同時点での面的な調査であるが、 クールスポット調査は同地点での継続的な調査である。具体的には、 周囲に比べて比較的気温が低いと判断されたポイント 40 カ所 (図 6 ) を抽出し、2 ケ月間の調査期間を設けて近隣の高津区民 20 名が参加 して調査を行った。また、そのうち、22 カ所についてはスポットの 特性やその周辺環境などの現地調査と評価を行つた。なお、特定の 地域の町会や自治会の協力を得るため、区域全域ではなく、2つの 区域を絞った中で 40 力所を選定した。

2) 調査手法

40 力所の実態調査では、参加者に温湿度計及び「クールスポット実 態調査カード」を渡して調査を行った（図 7 )。参加者は 3 日に 1 度 程度の頻度でクールスポットに行き、決められた調査項目について 調査を行った。定時ではなく任意の時間とし、参加者の生活ス夕イ

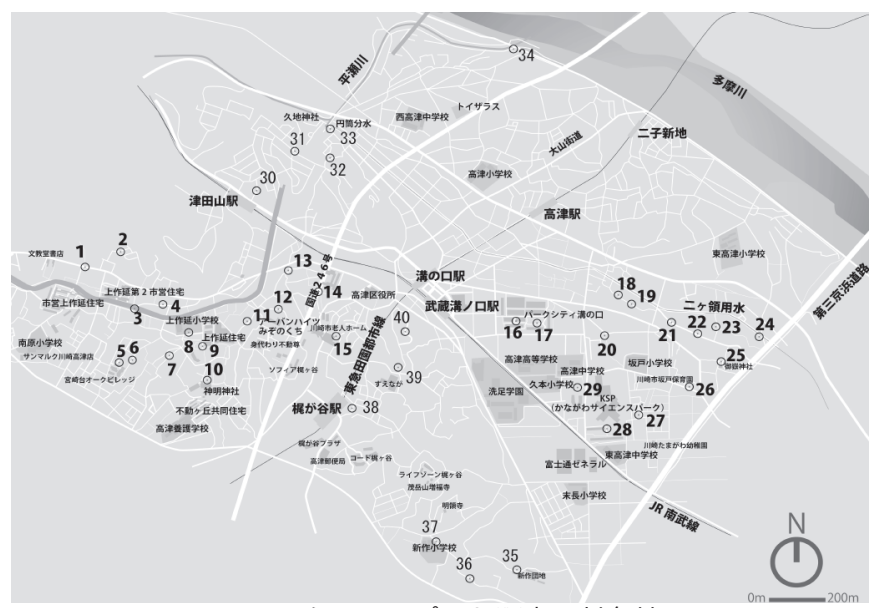

図 6 クールスポット調査の対象地 


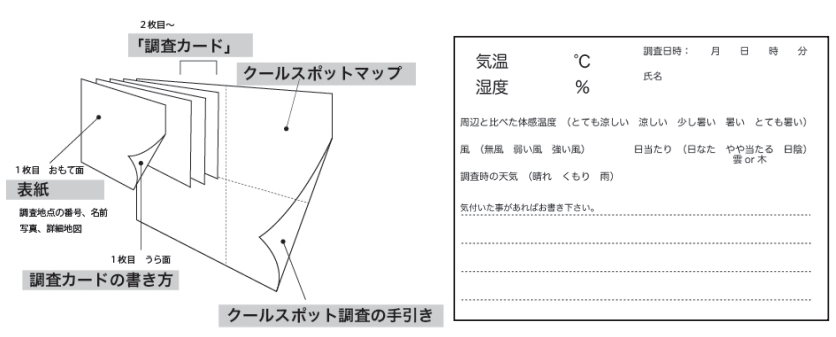

図 7 クールスポット実態調査カード （左：全体の構成、右：調査カード）

ルに合わせた調査を可能とした。

1 名が $1 \sim 3$ 力所を担当し、調査期間は 2010 年 8 月 1 日〜 9 月 30 日である。調査項目は温湿度計で計測した「気温」と「湿度」、 計測者が感じた「周囲と比べた体感温度」「風」「日当たり」「調査時 の天気」「気付いた事の自由記述」である。

40 力所の調査を行ったのち、調査結果より特に気温が低いクール スポット 22 カ所を選定し、3 日間にわたつてスポットの特性やその 周辺環境などの現地調査と評価を行った。具体的には参加者が 3 名 以上のグループとなってクールスポットに行き、周辺の環境を見て 「なぜここの気温が低いのか」についての共通認識をつくるとともに、 そのクールスポットの、気温や湿度以外の質的な状況について図 8 に示す 11 の項目で評価を行った。評価に参加した区民は 10 名であ る。現地に到着し周辺環境等を確認した上で個別に評価を行い、そ の評価を平均してそのクールスポットの評価とした。

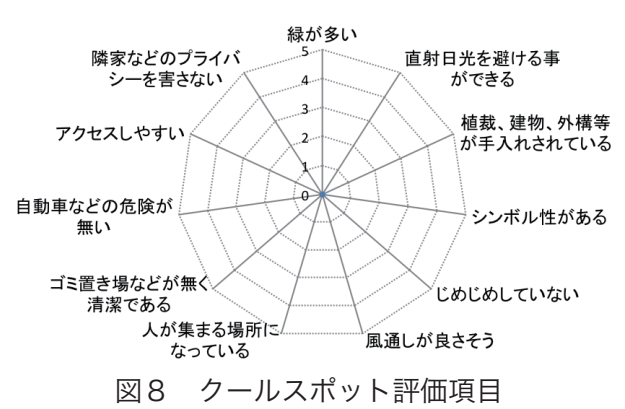

\section{3) 調査結果の概要}

40 力所の調査では全部で 931 の気温のデー夕を計測することがで きた。基準となる定点注 2) の気温変化と全デー夕をあわせて整理した ものの一部を図 9 に示す。また、図には調査の際に市民から寄せら れたコメントを抜粋して示す。定点の気温と比較して、クールスポ ットの気温は全体的に高くなっているが、これは定点の気温が小学 校の校庭の木陰にある百葉箱の中という、気温が低めに安定した環 境で計測されているからである。

22 力所の評価結果の一部を図 10 に示す。例えば「ザ・タワー\& パークス」は、大規模な新規開発マンションの公開空地である。事 前に地図で見た限りではやや殺風景ではないかとの意見があったが、 実際にはマンションの子供たちが多く遊ぶ姿がみられ、管理も行き 届いており全体的に評価が高かった。このような、温湿度だけでは ない質的な情報についても、市民参加型で調査を行つた。

4) 共有手法

40 カ所の調査結果を共有するために WEB サイト「クールスポッ

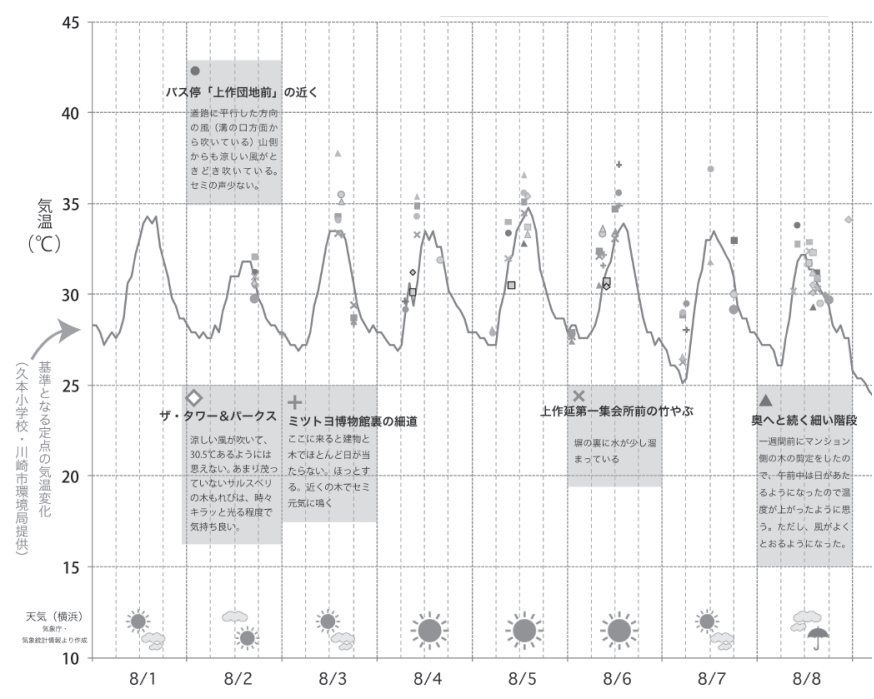

図 9 クールスポット調査結果（部分）

縦軸が気温、横軸が時系列であり、実線の折れ線グラフが基準となる定点の気温、記号が各 クールスポットの気温である。コメントは計測者が残したコメントである。クールスポット の記号は 40 カ所それぞれにユニークな記号をつけた。
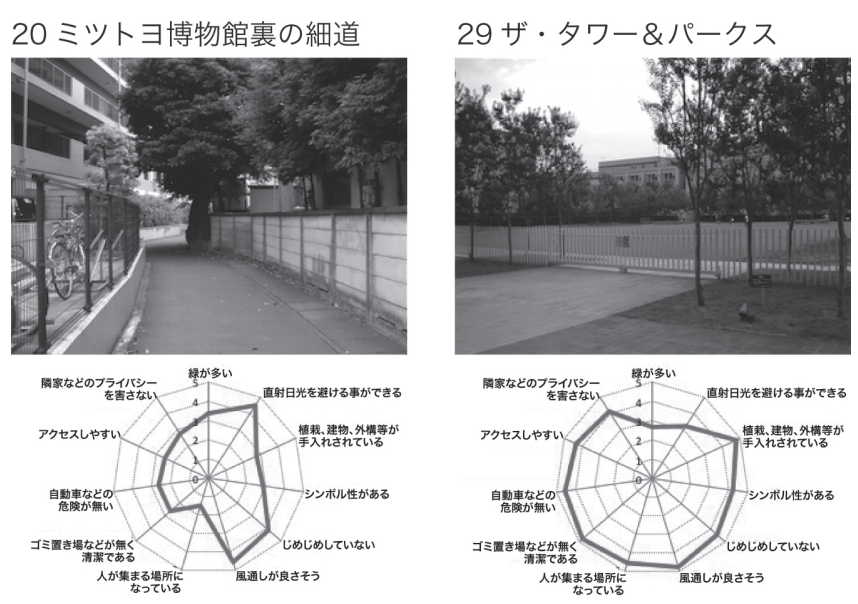

図 10 クールスポット評価の結果（部分）

卜調査報告」を開発した（図 11）。20 名の市民が 2 ケ月間にわたつ て同時平行で調査を行ったため、調査参加者が調査結果を自宅等か ら入力することが出来、他の調査者の結果も閲覧できるシステムで ある。サイトにログインし、報告をしたい、見たい調査エリアを選 択する。「報告する」をクリックすると報告画面に進み、調査の報告 が出来る。「結果を見る」とクリックすると、各スポットの調査結果 を見ることが出来る。なお、 $\mathrm{PC}$ での入力を希望しない参加者のデー

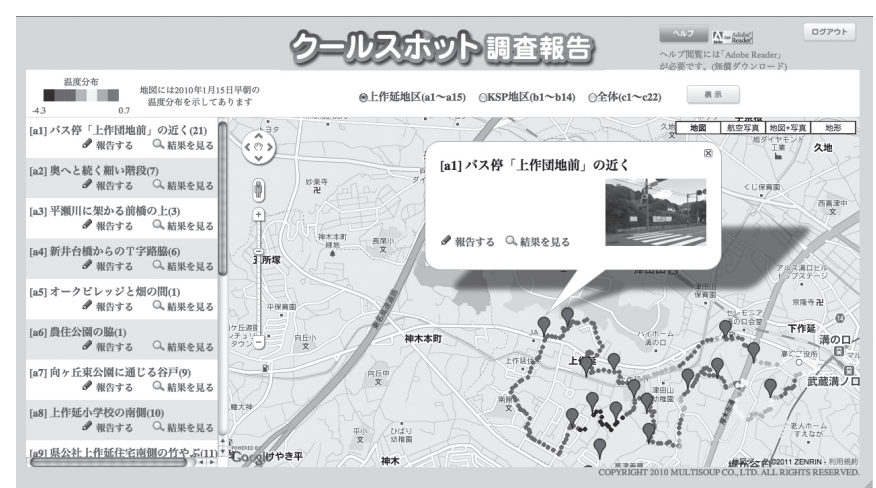

図 11 クールスポット調査報告 
タについては、大学スタッフで調査カードを回収して入力した。

\section{3 ワークショップ}

ワークショップは「街歩きによる気温実測調査」や、「クールスポ ット調査」の節目毎に行い、調查参加者で調査結果の振り返りや議 論を行った。2 年間を通じて 5 回のワークショップを開催した。

第 1 回 (2009 年 7 月) は、説明会を兼ねたものであり、ヒートア イランド現象の簡単な説明を大学側から行い、市民と地域特性や気 になる場所等の意見交換を行った。ここで得られた地域の特性や親 しまれている場所の情報は「街歩きによる気温実測調査」のルート 設定時の参考にした。

第 2 回 (2009 年 10 月) は、同年夏に行った「街歩きによる気温実 測調査」の結果を振り返るものである。調査結果から気温の低い場所、 気温の高い場所の違いを作り出している要因は何であるかという議 論を行なった。

第 3 回 (2010 年 3 月) は、それまでの調査結果 4 回分の結果を振 り返り、気温分布とその他の都市要素との関係を読み取った。ベー スとなる調査対象範囲の地図と、透明なフィルムに印刷した気温分 布、その他のデー夕（標高、総容積率、公園の割合、人口密度、建 物用途）を準備し、それぞれを重㪍て議論を行った。

第 4 回 ( 同年 7 月 ) は、新年度の調査の方向性の確認、および 8 月 から新たに行う「クールスポット調査」の概要を説明した。

第 5 回 (同年 10 月) は夏期の「街歩きによる気温実測調査」と「ク ールスポット調査」の振り返りである。図 9 のグラフを 2 ケ月分つ
なぎあわせたグラフを作成し、調査結果を共有した。最後にこれま でに得られたデータの使い道や今後の展開に関して議論を行った。

また、2011 年 3 月に本研究における一連の取り組みを市民へ広く 伝える事を目的として、調査の具体的内容や調査結果をわかりやす くまとめた冊子を作成し配布した注 3 )。

\section{5. 評価}

\section{1 概要}

「街歩きによる気温実測調査」「クールスポット調査」それぞれが、 参加者にどのように受け止められたのかをヒアリングによって明ら かにする。質問事項は気温変化が実感されたかという「実感」、調査 を経験しての気持ちの「変化」、調査に繰り返し参加するモチベーシ ヨンを維持した「継続要因」という 3 点を質問した。そして、全て の調査を経験した事によって「調査後、実際に始めた事があるか。」 「今後のデータ活用方法」等について質問した。ヒアリング対象者は、 ほぼ全ての調査とワークショップに参加した 5 名である（図 12)。

\section{2 参加者の属性と背景}

本研究への参加者は、高津区からの呼びかけ及び、友人同士での 誘い合いで集まった。ヒアリング対象者である 5 名は、現在何らか の形で区内の市民活動に参加している。活動内容は主に住環境の改 善に関するものであり、そのきっかけは、区役所へ退職後に取り組 む事を問い合わせたことや、区主催の環境講座への参加である。 氏は元高校教師、B 氏は化学関連の技術者、C 氏は元建築技術者、D

\begin{tabular}{|c|c|c|c|}
\hline & & A氏 & B氏 \\
\hline $\begin{array}{l}\text { 街 } \\
\text { 歩 } \\
\text { き }\end{array}$ & $\begin{array}{l}\text { 調査を通して都市の中 } \\
\text { での部分的な気温の変 } \\
\text { 化を薦する事はでき } \\
\text { ましたか。 }\end{array}$ & $\begin{array}{l}\text { 今まで考えていた事が数值と } \\
\text { なって表れてくるから良い。 } \\
\text { 風通しの良い地形が大切。公 } \\
\text { 園が重要。 }\end{array}$ & $\begin{array}{l}\text { いままで体感でしかなか } \\
\text { つたのが、数值やマップ } \\
\text { として記録・表現される } \\
\text { ことによる具体化 }\end{array}$ \\
\hline る & $\begin{array}{l}\text { 調査を経験することで } \\
\text { 都市空間の見方が変化 } \\
\text { しましたか。 }\end{array}$ & $\begin{array}{l}\text { 市への提案が自分の思い込み } \\
\text { では無いという実証である。 }\end{array}$ & 特に無し \\
\hline 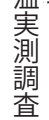 & $\begin{array}{l}\text { 調相を続ける事ができ } \\
\text { た理由を教えてくださ } \\
\text { い。 }\end{array}$ & $\begin{array}{l}\text { はっきり分かる。発見がある } \\
\text { ので楽しい。 }\end{array}$ & 特に無し \\
\hline ク & $\begin{array}{l}\text { 調査を通してクールス } \\
\text { ポットの涼しさを実感 } \\
\text { する事はできましたか }\end{array}$ & できた。 & 特に無し \\
\hline $\begin{array}{l}\text { ル } \\
\text { 杀 } \\
\text { ホ } \\
\text { ッ }\end{array}$ & $\begin{array}{l}\text { 調査を経験することで都 } \\
\text { 市空間の見方が変化しま } \\
\text { したか。 }\end{array}$ & $\begin{array}{l}\text { 変化はない。(家から駅までど } \\
\text { んどん暑くなる。元々感じて } \\
\text { いた事が証明された。) }\end{array}$ & 特に無し \\
\hline 占 & $\begin{array}{l}\text { 調査を続ける事ができ } \\
\text { た理由を教えてくださ } \\
\text { い }\end{array}$ & $\begin{array}{l}\text { WEB で他の人のを見えるの } \\
\text { が良かった。自分のスポット } \\
\text { がどうかすぐにわかり比較で } \\
\text { きた。 }\end{array}$ & $\begin{array}{l}\text { 特になし。たくさんの } \\
\text { 方々にお願いしている } \\
\text { 手前、やらざるを得な } \\
\text { い。 }\end{array}$ \\
\hline & $\begin{array}{l}\text { 調査を経験してから実際 } \\
\text { に始めたととあります } \\
\text { か。 }\end{array}$ & 特に無し & 特に無し \\
\hline $\begin{array}{l}\text { 今 } \\
\text { 後 } \\
\text { に } \\
\text { つ. }\end{array}$ & $\begin{array}{l}\text { 今までの調査によって得 } \\
\text { られたデータによて何 } \\
\text { ができると思われますか }\end{array}$ & $\begin{array}{l}\text { コミュニティが作れるのでは } \\
\text { ないか。調査範囲を全区に広 } \\
\text { げたいい。 }\end{array}$ & $\begin{array}{l}\text { ワークショップなどの機 } \\
\text { 会を通して新たな方向性 } \\
\text { が見えてくると思う。 }\end{array}$ \\
\hline$\frac{\omega}{\tau}$ & $\begin{array}{l}\text { それは誰がすべきだと思 } \\
\text { われます }\end{array}$ & $\begin{array}{l}\text { 市民主体。まちづくり協議会 } \\
\text { 町会、ベンチに町会や企業 } \\
\text { の名前を。 }\end{array}$ & よくわからない \\
\hline & $\begin{array}{l}\text { 今おこなっている環境活 } \\
\text { 動に活かすことはできそ } \\
\text { うですか。 }\end{array}$ & $\begin{array}{l}\text { ヒートアイランドの調査の } \\
\text { 活動を市全体に広げる。 }\end{array}$ & なんとも言えない。 \\
\hline
\end{tabular}

C氏

\begin{tabular}{|c|}
\hline 風通しがあるとこころ感じた。 \\
\hline $\begin{array}{l}\text { 用途地域が全国一律なのが } \\
\text { 合くな゙た地し域に計画が必要。 }\end{array}$ \\
\hline 知りたいから \\
\hline
\end{tabular}

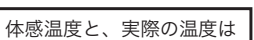
違うという事が分かった。 緑や隣棟間隔をより意識 するようになった。

知りたいから

周りの人達に話ができる 。マンションの管理組合 の人たちに話をしている まずは、クールスポット があるという事から知ら せる事だと思う。

区民会議などで発表して いとと良い。

「みどりのまちづくり」と
いうグループで散歩道を作
つている。これに何か組み
込める可能性はある。

D氏

\begin{tabular}{|c|}
\hline $\begin{array}{l}\text { はっきりわかった。緑が影響 } \\
\text { しているんだろうと予測はし } \\
\text { ていてが、際にデータとし } \\
\text { ていたがん出てきた。 }\end{array}$ \\
\hline $\begin{array}{l}\text { できるだけ涼しいところを作ら } \\
\text { なくてはいけい。緑を多くす } \\
\text { る必要性を一段と感じた。 }\end{array}$ \\
\hline $\begin{array}{l}\text { 途中でやめるのは嫌。データ } \\
\text { の行く末が気になった。のオ } \\
\text { 一キングをやっているのでそ } \\
\text { の延長の感覚。 }\end{array}$ \\
\hline
\end{tabular}

の延長の感覚。

\begin{tabular}{|c|}
\hline $\begin{array}{l}\text { 体感温度と実際の気温のギャ } \\
\text { ップ }\end{array}$ \\
\hline $\begin{array}{l}\text { 予想気温より計測した気温の } \\
\text { 方が高かった。地面から輻 } \\
\text { 射であると熱でえた。しかし考え゙本当の気。 } \\
\text { それか温。 }\end{array}$ \\
\hline 健康のため。 \\
\hline
\end{tabular}

\section{老人会で調査の事について報} 告した。

散歩コースにクールスポット を組み込むことなど。何をや るにせよ、デー夕を外に対して 行政と市民による協力

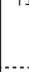

E氏

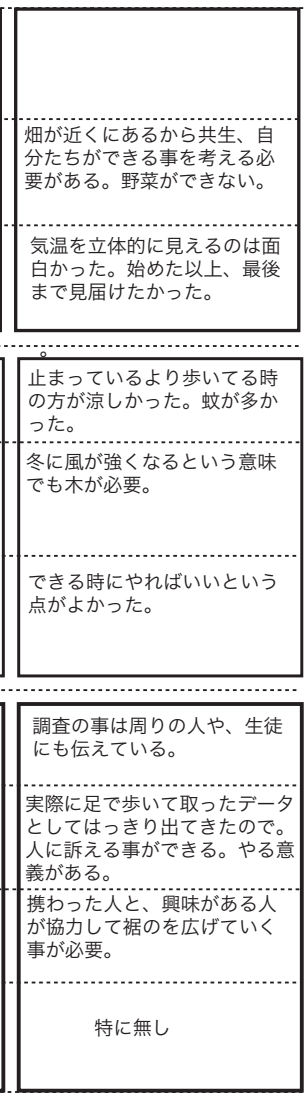

図 12 ヒアリング調査の結果 
氏は元会計関係の職種、E 氏は数学講師である。

\section{3 市民参加型調査の評価}

\section{1) 街歩きによる気温実測調査の評価}

\section{(1)都市の中での部分的な気温変化の実感}

5 名ともに「デー夕化されることによる暑さ、涼しさの実感」が できたとの回答であった。日常的に都市の中の暑さ、涼しさの違い を感じていたが、はっきりとデー夕化、視覚化された事によって、 改めて暑い場所、涼しい場所を確認する事ができたと考えられる。

\section{(2)都市空間の見方の変化}

大きな変化は見られないが、「緑を多くする必要性を感じた」とい うように、参加者がこの調査によって緑地の減少は都市を暑くする という一般的に言われている事に確信を得たことがわかる。

\section{(3)調査を続ける事ができた理由}

3 名が「始めた以上中途半端に終えたくなかった」と答えている。 地道な調査手法であり、毎回楽しみにしている様な回答は無い。今 後参加者を多く募る事を考えた場合にこの点は課題である。

2) クールスポット調査の評価

(1)クールスポットの涼しさの実感

概ね涼しさの実感は得られた。2名が「体感温度と計測した温度の ギャップ」を印象的な経験として挙げている。

\section{(2)都市空間の見方の変化}

一致した回答は無く、道路上の気温が生活する上での本当の気温 であることを意識するようになった、樹木が全く無いと夏に暑く、 冬に風当たりが強いため、樹木の有効性を認識した、という回答が 得られた。

\section{(3)調査を続ける事ができた理由}

「健康の為になる」のように、散歩の一環としてこの調査がうまく 利用できたという回答を得た。また、「WEBで他の担当者が行った 調査結果を閲覧できるから」というようにデー夕共有の仕組みが実 を結んでいる事も確認できた。また「できる時にやれば良い」とい う調査の縛り付けない自由な調査方法が続けられた理由であるとい う回答も見られた。

\section{3) 今後の活動について}

\section{(1)調査を終えてから実際に始めた事}

3 名が周囲の人々に対して話をしていた。その対象は、マンション の管理組合、老人会、講師として教えている生徒に対してなど多様 なシーンで行われている事が分かった。

(2)今までの調査によって得られたデータで何が出来るか

3 名から、何をするにしてもまずはクールスポットがあるという 事を周知させる事が必要であるという趣旨の意見が得られた。また、 クールスポットを利用したコミュニティができるのではないだろう かという意見もあった。これはクールスポットを使って街を歩いて いる中で腰を降ろしたり、一休みするような場所を作り、地域に役 立てていくという今後の発展が期待される意見である。

\section{6. まとめ}

本研究では特定の地域を対象として、市民が参加してヒートアイ
ランド現象を調査し、その結果を地域で共有する市民参加技術の開 発を行った。そして、これらの手法がどう地域社会に影響をもたら したのかを明らかにするため、参加した市民へのインタビュー調査 を行い、手法の評価、今後の展望について明らかにした。本研究で 開発した技術は参加者に対して大きな発見をもたらす様なものでは 無いが、目に見えない都市の温熱環境を生活空間がイメージできる 詳細なスケールで明らかにできたという点で有効であった。

本研究は研究者が発意したものであり、政策の中で戦略的な位置 づけがなされて行われたものではない。そのため、他の施策への展 開は十分ではないが、 2 年間の研究期間を経て、データが蓄積され、 一定の意識も形成出来ている。実際に何らかの対策行動が行われて いくには、世論がより喚起される、行政で施策化される、リーダー シップを持った市民が現れる、などの諸条件がさらに整ってからの ことになると考朰れる。その際に、本研究で開発した手法でウェ ブサイトで情報が共有されているなど、一定の環境は形成されてい るので、何らかの対策行動につながり、中長期的なヒートアイラン ド対策が実現していく事が期待される。

また、本研究で開発した開発した手法を政策的に位置づけるとす れば、例えばグリーンカーテンや緑化、風の道の設置といった具体 的な対策とあわせて実施し、こういった対策がどういった気温変化 をもたらすかを計測、共有するための手法として活用が可能である。

謝辞

1 研究にご協力をいただいた高津区市民の皆様，およびデー夕提供等にご協力 をいただいた川崎市役所に記して感謝いたします。

2 この研究は第一住宅建設協会（現「都市のしくみとくらし研究所」）の研究 助成を受けて行われた「ミクロな生活空間に扔ける都市温熱環境の実態と市 民主体の都市計画によるヒートアイランド対策手法の開発」の成果である。

3 この研究は首都大学東京「巨大都市の Built Environment の持続的改善技法 育成」研究グループ (代表：小林克弘）の研究成果である。

4 WEB サイトによる情報共有手法の開発にあたっては、システムの共同設計 者としてマルティマルティスープ (株) の多大な協力を得た。開発に携わつ た小林啓志氏、那須俊宗氏に記して感謝いたします。

補注

1) エコシティ高津の一連の取り組みはウェブサイトで公開されており、本研究 の成果もそこで公開されている。http://www.city.kawasaki.jp/67/67tisin/ eco city/index.html

2)川崎市環境局では市内 19 力所の小学校において継続的に気温を計測してお り、本研究対象地域内にある久本小学校に打ける計測デー夕を利用した。

3) 冊子を登表し、最終的な意見交換を行うワークショップを 2011 年 3 月に 予定していたが、東日本大震災の影響で中止された。なお、報道等で本研究 の取り組みが取り上げられたこともあり市民の問い合わせが増加したため、 2011 年 7 月に簡易版の「クールスポットマップ」を作成、印刷して配布した。

参考文献

1) 田中貴宏, 山下卓洋, 森山正和 :「都市環境気候図」を利用した多主体参加型 まちづくりワークショップに関する研究〜神戸市長田区駒ヶ林地区における ワークショップの実践, 日本建築学会環境系論文集, pp.91〜98, 2007.01

2) 日本建築学会環境工学委員会都市環境・都市設借運営委員会都市環境気候図 小委員会 : 気候に配慮した長野市のまちづくりのワークショップ, 日本建築 学会技術報告集 (24), 229-232, 2006-12-20

3) 日本建築学会環境工学委員会都市環境・都市設備小委員会クリマアトラス 実用化ワーキンググループ: 仙台都市域を対象としたワークショップによる 気候解析図と計画指針図作成の試み, 日本建築学会技術報告集，183-186, 2004.12

4) 日本建築学会環境工学委員会環境設計小委員会クリマアトラスの実用化 ワーキンググループ: 北九州ワークショップによるクリマアトラス気候 解析図と計画指針図作成の試み，日本建築学会技術報告集 (18), 203-206, 2003-12-20

5) 日本建築学会環境工学委員会環境設計小委員会クリマアトラスの実用化ワ ーキンググループ: クリマアトラスの実用化に関する研究：ワークショッ プによる計画指針図作成の試み，日本建築学会技術報告集 (14), 207-210, 2001-12-20

6) 増田 幸宏 , 岡留 智史, 鍵屋 浩司, 高口洋人, 高橋信之, 尾島俊雄 : 市民参 加による都市環境気候図作成に関する研究 --「市街地の暑熱環境体感ッアー」 の試み， 日本建築学会技術報告集，pp.215～219,2010.2 